International JOURNAL OF MULtidisciplinary REsearch AND ANALysis

ISSN(print): 2643-9840, ISSN(online): 2643-9875

Volume 04 Issue 07 July 2021

DOI: 10.47191/ijmra/v4-i7-10, Impact Factor: 6.072

Page No.- 929-938

\title{
Public Expenditure and Inflation in Nigeria
}

\author{
Lubo Ebisine ${ }^{1}$, Bigbo Oki ${ }^{2}$ \\ Department of Economics, University of Africa, Toru-Orua, Bayelsa State, Nigeria
}

\begin{abstract}
This paper empirically examined the effect of public expenditure on inflation in Nigeria in Nigeria from 1981 to 2018. The study adopts descriptive statistics, Co-integration and Error Correction Mechanism techniques for the analysis. The data for the empirical analysis were sourced from secondary sources like CBN Statistical Bulletin. The results of analysis indicated that a long run relationship exists among the variables. Furthermore, the paper revealed that government expenditure on transport and communication (XTCM) has a positive but insignificant relationship with inflation (CPI) at 5 percent level; government expenditure on defense (XDFS) is positive and an insignificant effect on inflation (CPI) in Nigeria; government expenditure on agriculture (XAGR) is negative and an insignificant effect on inflation (CPI) in Nigeria; government expenditure on education (XEDU) is positive and an insignificant effect on inflation (CPI) in Nigeria and government expenditure on health (XHLT) is negative and an insignificant effect on inflation (CPI) in Nigeria. Based on the above findings, the paper recommends as follows: Government should be effective in channeling public funds to productive economic activities, which will enhance price stability in Nigeria. Also, government consumption spending should be well coordinated by all arms of government to prevent "Crowd out" effect on government investment.
\end{abstract}

KEY WORDS: Public Expenditure, Transport and Communication, Defense, Agriculture, Education, Health and Inflation (CPI).

\subsection{INTRODUCTION}

Public expenditure is one of the fiscal policy measures in which government use to provide public goods such as defense, roads, education, health and power to mention a but few. It is used by government to stabilize the economy when there is imbalance resulting from economic problems such as inflation, recession, stagnation. On the other hand, inflation is the sustained general rise in price level in the economy.

According to Ezirim, Mudghalu, Elike, (2010), the relationship between public expenditure and domestic price level have been theorized by the Keynesian economics who believed in using fiscal policy in solving most of the economic problems such as inflation, stagnation and recession.

Inflation, being a general problem is not peculiar to Nigeria alone. It is an economic problem facing developed and developing countries. In a conference organized jointly by Central Bank of Nigeria (CBN) and Nigerian Institute of Social Economics Research in 1974 at Ibadan on "Inflation in Nigeria" majority of the participant came up with the view that money supply, government expenditure, limitation in real output and the existence of structural rigidities and bottlenecks in the economy as major causes of inflation in the economy of Nigeria. More so some scholars did not agree using monetary growth, such scholars in explaining inflation. Studies carried out by Akinnifesi (1977, 1984), Adeyeye and Fakiyesi (1980) and Osakwe (1983), failed to produce consensus on monetary growth but rather on the view of non-monetary variables in explaining inflation in Nigeria in the case of introducing structural Adjustment Programme SAP (Asogu, 1991).

Meanwhile, the Nigerian economy is facing with the problem of unemployment and inflation (stagflation) at the same time. Recently, the last quarter of 2019, when the boarders were closed by the Nigerian government there was a rise in prices of goods which gives rise to the annual inflation rate in Nigeria rose to 11.85 percent in November of 2019 from 11.61 percent in the prior month (National Bureau of statistics Nigeria). To solve the problem of inflation the government of Nigeria has adopted various stabilization measures, such as fiscal and monetary policy respectfully.

In view of the above, there is need for the Nigeria government to spend in order to stabilize the economy, enhance productivity or investment through direct public spending and investment according to Keynesian view (Olayunbo, 2013). This is resulted in increased spending by government both in recurrent and capital expenditure due to increasing revenue from Oil and the increase demand for public goods like roads, education, health facilities, defense and increasing population. 


\section{Public Expenditure and Inflation in Nigeria}

Unfortunately, rising government expenditure has not translated to meaningful growth and development as Nigeria ranks among the poorest countries in the world. More so, there is dilapidated infrastructure (especially roads and power supply that led to the collapse of many industries, including high level of unemployment. Still, macroeconomic indicators such as inflation rate, exchange rate, balance of payments and national savings reveals that Nigeria has not done well in the last couple of years (CBN 2011).

It is assumed that when government spends too much money relative to the availability of goods and services in the economy, there is that tendency that it will lead to corresponding increase in prices, which gives rise to inflation spirals, ceteris paribus (Ezirim, Muoghalu and Elike, 2010). There has been a debate on government expenditure growth and inflation over the years. The argument had centered on whether public expenditure growth has the potential to induce inflation. While some scholars are of the view that public expenditure growth can influence inflation, others are of the view that it is inflationary pressure that causes the growth of government expenditure in both developing and developed countries (Ezirim, Muoghalu and Elike, 2008). In spite of this, there is still on unsolved issue theoretically as well as empirically as to the effect of government expenditure on inflation. Although, the theoretical position on the subject matter are quite different, yet the conventional assumption is that government expenditure growth can result to price instability. However, empirical studies does not conclusively support the conventional wisdom opined by Mesgbena (2006), in the work of Olaiya, Nwosa and Amassoma, (2012). Scholars like Nyambe and Kanyeumbo (2015), Egbulonu and Wobilor (2016), Mehraraa, Soufianib and Rezaei (2016) e.t.c have found that public expenditure impact positively on inflation, others like Olayunbo (2013), Peter (2015) etc are of the view that public expenditure negatively impact on inflation. Other studies like Ogbonna (2014), Ojarikre, Ezie and Torka (2015), Ogbole and Momodu (2015), etc did not find any relationship. In spite of various policies measures to stabilize the economy, reduce inflation and the inconclusive debate in respect of public expenditure growth and inflation motivated this study. This is the gap; the study seeks to address in the literature. Therefore, the study is to analyze the effect of public expenditure growth and inflation in Nigeria for the period $1981-2018$. The rest of this paper includes literature review, methodology, results and discussion and then conclusion and recommendations.

\subsection{THEORETICAL LITERATURE}

\subsection{Conceptual Framework}

Public expenditure is the total expensed incurred by the government in form of providing social amenities on various sector of the economy. Maku (2009) stressed that the structure of Public Expenditure will determine the pattern and form of growth in output of the economy. According to Anyanwu (1997), public expenditure structures addresses the question of how the expenditure is or should be patterned. The structure of public expenditure is usually categorized into recurrent and capital expenditure. The recurrent expenditure is composed of administration (general administration, defense, internal security), economic services (agriculture, construction, transport and communications and others); social and community services (education, health and others), and transfers. In the same vein, capital expenditure includes administration, economic services, social and community services and transfers.

Musgrave and Musgrave, (2004), Anyanwu (1997), Maku (2009), Bhartia (2006), says these expenditures can be used to provide necessary economic infrastructure for the development of selected economic activities and can be used to give subsidies for increasing their profitability.

On the other hand, inflation is the continues and appreciable rise in general price level (Jhingan 2004). Not every increase in price is termed inflation. For a rise in general price level to be considered inflation, such a rise must be constant, enduring and sustained. Every commodity should be affected in the increase in price level, and must not be temporal. Vaish (2003) viewed inflation as condition which is considered to be a rising trend in the general price level in the economy. It is also a sustained rise in the general price level which brought about by high rate of expansion in the aggregate money supply. But Dembery and McDougall refer to inflation as a continuing rise in prices as measured by an index such as the consumer price Index (CPI) or by the implicit price deflator for Gross National Product (Jhingan 2004). In an inflationary economy, it is difficult for the national currency to act as medium of exchange and a store of value without having an adverse effect on income distribution, output and employment (CBN, 1984).

There are three approaches to measurement of inflation. These are the Gross National Product (GNP) complicit deflator, the Consumer Price Index (CPI) and the Wholesale or Producer Price Index (WPI or PPI). The period to period changes in these two latter approaches (CPI and WPI) are regarded as direct measures of inflation. None of the three methods singly, uniquely best measure inflation. The Consumer Price Index (CPI) approach as the least efficient of the three is used to measure inflation rate in Nigeria as it is easily and currently available on monthly, quarterly and annual basis (CBN, 1991). There are different names given to inflation depending upon the rate of rise in prices (Jhingan, 2004). These include: creeping inflation, walking or troffing inflation and running inflation. 


\section{Public Expenditure and Inflation in Nigeria}

\section{2 Inflation in Nigeria}

There has been inflation in Nigeria right from when the government in 1960s propelled the "Cheap money policy" to stimulate development after independence. Interest rate were lowered and geared towards critical sectors of the economy, including the facilitation of the First National Development Plan. This led to monetary expansion with the narrow and broad measures of money stock (M1 and M2 respectively) rising at annual rates of $29.7 \%$ (1961) and $44 \%$ (1969). Consequently, inflation increased from $6.4 \%(1961)$ to $12.1 \%$ (1969).

The Oil boom era of 1979 was characterized by fiscal dominance and sever macro- economic imbalance as there was increase government revenue in foreign exchange from Oil export. In 1971, the revenue rose from six hundred and three million ( $\$ 603.0 \mathrm{~m}$ ) to Ten billion, four hundred and thirty three million, one hundred thousand naira $(10,433.1 \mathrm{~m})$ with a share in the total revenue of $52.46 \%$ (1971) and $88.89 \%$ (Suleiman, 1998). Reluctantly, the government injected massive private and public expenditure into the economy through enormous post war reconstruction of the early 1970's and expenditure on the gigantic capital embarked upon by all the governments under the third national development plan (Suleiman 1998). Also, the Udoji Committee which doubled the basic minimum wage in the public sector in 1975 represented a climax in inflationary tendencies that led to the widespread strikes and unrest in the private sector on which Udoji recommendations were not binding.

Furthermore, the introduction of Structural Adjustment Progamme (SAP) in 1986 led to temporal reduction in fiscal deficits as government removed subsidies and reduce her involvement in the economy. With the introduction of Structural Adjustment Programme (SAP) there was fall in growth rate of Gross Domestic Product (GDP) in 1990 from 8.3\% to 1.2\% in 1994, with inflation rising from 7.5\% (1990) to 57.0\% (1994), also the devaluation of the naira by Central Bank of Nigeria (CBN) through the Second Tier Foreign Exchange Market (SFEM) led to a fall in the Agricultural outputs as machines and raw materials (mostly importers) were out of reach. The devaluation reduced the aggregate real income and aggregate demand and at the same time raised the naira prices of good whose production depended heavily on imported goods.

\subsection{Theoretical Framework}

2.3.1 The Keynesian approach to demand pull inflation: This theory emphasis the increase in aggregate demand as the source of demand pull inflation. There may be more than one source of demand. Consumers want more goods and services for consumption purposes. Business men want more inputs for investment. Government demand goods and services to meet civil and military requirements of the country. Thus the aggregate demand comprises consumption, investment and government expenditures. When the value of aggregate demand exceeds the value of aggregate supply at the full level of employment, the inflationary gap arises. The Keynsian theory is based on a short run analysis in which prices are assumed to be fixed. In fact prices are not determined by non- monetary forces. Conversely, output is assumed to be more variable which is determine largely by changes.

2.3.2 Monetary Theory of Inflation: The monetarists emphasize the role of money as the principal cause of demand-pull inflation. They argued that inflation is always a monetary phenomenon. Its earliest explanation is to found in the simple quantity theory of money. The monetarist employed the familiar identity of fisher's Equation of Exchange:

$\mathrm{MV}=\mathrm{PQ}$

Where $M$ is the money supply, $V$ is the velocity of money, $P$ is the Price level and $Q$ is the level of real output. The modern quantity theorist led by Friedman hold that inflation is always and everywhere a monetary phenomenon that arises from a more rapid expansion in the quantity of money than in total output. He contends that changes in the quantity of money will work through to cause changes in nominal income. Inflation everywhere is based on an increased demand for goods and services as people try to spend their cash balances.

\subsubsection{Keynesian Theory of Public Spending:}

According to Maynard Keynesian, government expenditure is used as a stabilization tool. Keynesian view during the Great Depression in the 1930's was that output and employment were below their potential level because there was insufficient total demand. If demand could be increased, output and employment could be expanded and invariably the economy will return to its full employment potential. Keynesian believed that expansionary fiscal policy will be used to achieve full employment.

In the period of a recession, Keynesian argued instead of balance budget, government should increase its spending, reduce tax and shift the budget towards a deficit. This will directly increase total demand. On the other hand, if the economy was experiencing a problem with inflation during economic boom, according to Keynesian, there should be a restrictive fiscal policy to reduce excessive demand. This will be led to reduction in government spending, higher taxes, and a shift of budget towards budget surplus. This will reduce total demand and thereby help to fight inflation. 


\section{Public Expenditure and Inflation in Nigeria}

\subsection{Empirical Review of Literature}

The review of literature reveals that similar studies have been carried out on the relationship between Public expenditure and inflation by Scholars in both developing and developed countries. Aizenman and Hausman (2000), investigate budgetary rules for an economy characterized by inflation and volatile relative price. In the absence of shocks, the design of the budget is that the Treasury allocates funds once in every budget cycle. They use a panel data for Argentina, Brazil, Chile, Columbia, Costa Rica, Caribbean, Salvador, Guatemala, Hondieras, Mixico, Peru, and Venezulea, for the period 1970 -1994. The correlation between the budget error and the inflation variable turned out to be high and highly significant.

Kia (2006) studying Iranian economy for the period 1970-2002, focuses on the internal and external factors, which influence the inflation rate in developing countries. According to the estimation results, over the long run, a higher exchange rate leads to a higher price in Iran. So, a policy regime that leads to a stronger currency can help to lower inflation. However, a higher money supply when it is anticipated does not lead to a higher price level, but an unanticipated shock in the money supply results in a permanent rise in the price level. It is also found that the fiscal policy is very effective in Iran to fight inflation as the increase in the real government expenditures as well as deficits cause inflation, but if the changes are unanticipated, they cause the opposite effect while a high debt per GDP is deflationary.

Ezirim, C.B, Muoghalu, M.I and Elike, U, (2008), in their work tittle inflation versus public expenditure growth in the US: An Empirical Investigation using co-integration analysis and Granger causality model found out that inflation significantly influences public expenditure decision in the United States of America. Public expenditure growth was seen to aggravate inflationary pressures in the country, where reduction in public expenditure tends to reduce inflation.

Ozurumba (2012) examines the causal relationship between inflation and fiscal deficits in Nigeria from 1970 to 2009 , using autoregressive distributed lag (ARDL) model and the Granger availability tests. From his results of the ARDL test, it was observed that there exists a significant negative correlation between growth in fiscal deficit and innovations in the rate of inflation which is in conformity with expectation. The study recommended that policies targeted at inflationary control in Nigeria may be most effective if they are targeted at reduction in fiscal deficits and by extension, government should support growth in the real sectors of the economy.

Medee and Nnebee (2012) examined fiscal deficits and inflation in Nigeria from 1980 to 2010 using the ordinary least square (OLS) technique of multiple regression for the study. The result showed that both inflation rates were rightly sign with fiscal deficits. Despite this theoretical congruence, inflation rates impacted on fiscal deficits while interest rate does not. To this extent, they suggested that there is need to reorder Nigeria's fiscal policy priorities based on sincerity so as to rebuild confidence in the economy.

The same vein, Everton, Vincent and Wilson (2012) employed the vector error correction modeling technique to investigate the long-term relationship between fiscal deficits and inflation for Nigeria. The empirical results show that there is a positive but insignificant relationship between fiscal deficits and inflation. The analysis of the Nigeria data also indicate a tenure link to previous levels of fiscal deficits with inflation and provide, moreover, evidence of a positive long-run relationship between money supply growth and inflation, suggesting therefore that money supply growth is pro-cyclical and tends to grow at a faster rate than the rate of inflation.

Olayungbo (2013) examined the causal relationship between government spending and inflation in Nigeria for the period of 1970 to 2010. The study used Granger causality test and the Vector Auto-regression (VAR) modeling techniques for the analysis. The study found that a uni-directional causality exists from government expenditure changes (Low or contractionary government spending) to inflation changes (high inflation). The finding implies that inflationary pressure in Nigeria is state dependent, that is, high inflation is caused by low or contractionary government spending.

Muhammad and Attiya (2013) explores the relationship among the rate of inflation, economic growth and government expenditure in Pakistan from 1980 to 2010 using Autoregressive Distributed Lag (ARDL) model and Granger-causality tests. The outcome of the estimations identified a long-term relationship amongst rate of inflation, economic growth and government expenditure; it means that government expenditures yield positive externalities and linkages.

Ogbonna (2014), investigated the effect of government size and developments on consumer price index in Nigeria for the period between 1981 to 2013. The study employed co-integration and vector error correction model (VEM) methods to analyze the data. The result indicate that a long run equilibrium relationship exists between consumer price index and government size in Nigeria. Also no long-run causal relationship was identified between consumer price index and government expenditure in Nigeria and there is no short run causality running from government expenditure to consumer price index in Nigeria.

Ogbole and Momodu (2015) investigated the nature and extent of causal relationship between government expenditure and inflation rate for a period of 42 years spanning from 1970 to 2011. The study employed the Johansen co-integration test and Granger causality test analysis. The variables are stationery, weakly and inversely correlated and show long run relationship. 


\section{Public Expenditure and Inflation in Nigeria}

However, they did not granger cause each other. Implying that there exists no causality between them. They recommend appropriate Fiscal monetary policy mix, redirecting government expenditure to productive channels in the economy and maintain a strategic balance between capital and recurrent expenditure.

Ojarikre, Ezie and Torka (2015) examined empirically the causal relationship existing between public expenditure growth and inflation in Nigeria from 1981 to 2012. The study employed econometric techniques of Johansen co-integration test and the Granger causality test. The found that the Johansen co-integration techniques indicated the presence of co-integration among the variables. It also found that there is no statistically discernible relationship between government expenditure growth and inflation in Nigeria.

Egbulonu and Wobilor (2016) examined the relationship between fiscal policy and inflation rate in Nigeria from 1970 to 2013. The study used the co-integration, Granger causality test, Ordinary Least Square (OLS) regression and Error Correction Mechanism $(E C M)$, techniques to analyze the data. The results found a statistically insignificant positive relationship between government expenditure; government tax revenue and inflation in Nigeria, while government debt stock is positive and statistically significant. The study recommends that government should implement viable fiscal policy and monetary policy mix as well as diversify the nation's economic base.

Mehraraa, Soufianib and Rezei (2016) examined the nonlinear relationship between inflation and government spending using quarterly data over the period of $1990-2013$ by using smooth Transition Regression Model. The study showed that in regime of tight money or low growth of liquidity, government expenditure is not inflationary. So fiscal policies could be used to control inflation and stimulate aggregate demand in low regime. Also, in easy money regime, monetary and fiscal discipline can be useful for inflation decrease.

Cynthia (2018) examines the effect of public spending on inflation in Nigeria from 1980 to 2017. The Auto Regressive Distributed Lag (ARDL) was used to analyze the relationship between public spending and inflation in Nigeria. The result shows that government capital spending impacts negatively on inflation; government recurrent spending has a negative and insignificant impact on inflation. Also, money supply has both a positive and negative impact on inflation, while exchange rate has a positive and insignificant impact on inflation. Based on these findings it is recommended that government needs to ensure appropriate channeling of its expenditure to infrastructural development in order to stimulate investment and production thereby stabilizing price.

\subsection{Summary of Literature Reviewed and Research Gap}

From the literature reviewed, it was observed that some studies on the effect of public expenditure and inflation have been carried out. Meanwhile, most of the works reviewed examine the effect of public expenditure and inflation consider using, three and four independent variables. But the present studies deviate from these scholars by examining public expenditure and inflation on Transport and communication expenditure, Defense expenditure, Agriculture expenditure, Education expenditure and health expenditure. Besides these variables, the period of study extends from 1981 to 2018 . This is the gap the study filled in the literature.

\subsection{METHOD OF STUDY}

\subsection{Data Required and Sources}

The required data to examine the effect of Public expenditure and inflation in Nigeria is tested based on time series data spanning from 1981 to 2018.

The data were sourced from the Central Bank of Nigeria (CBN) statistical bulletin and World Bank database.

\subsection{Analytical Framework}

The analytical framework of this study mimics the previous studies such as Cynthia, (2018) with further modification. Cynthia, (2018), who studied public expenditure and inflation, used inflation (INF) as dependable variable whereas public capital spending, public recurrent spending, money supply and Exchange rate as independent variables. But the present study deviates from these scholars by looking at public expenditure and inflation using Consumer Price Index (CPI) as dependable variables and Transport and Communication expenditure, Defense expenditure, Agriculture expenditure, Education expenditure and Health expenditure as independent variables.

Hence the functional model is specified as:

$$
C P I_{t}=f\left(X T C M_{t}, X D F S_{t}, X A G R_{t}, X E D U_{t}, X H L T_{t}\right) .
$$

The OLS linear regression equation based on the above functional relation is:

$$
C P I_{t}=\beta_{0}+\beta_{1} X T C M_{t}+\beta_{2} X D F S_{t}+\beta_{3} X A G R_{t}+\beta_{4} X E D U_{t}+\beta_{5} X H L T_{t}+\mu_{t}
$$

Transforming equation 3.2 to the natural logarithm, we have: 


\section{Public Expenditure and Inflation in Nigeria}

$$
\log C P I_{t}=\beta_{0}+\beta_{1} \log X T C M_{t}+\beta_{2} \log X D F S_{t}+\beta_{3} \log X A G R_{t}+\beta_{4} \log X E D U_{t}+\beta_{5} \log X H L T_{t}+\mu_{t}
$$

The essence of the transforming equation 3.2 to logarithm is because it helps to improve the validity of the estimates and it cause the variables to be at linear and of the same order.

Where:

$\mathrm{CPI} \quad=\quad$ Consumer Price Index

$\mathrm{XTCM}=\quad$ Government Expenditure on Transport and communication

XDFS $=$ Government Expenditure on defense

$\mathrm{XAGR}=$ Government Expenditure on Agriculture

XEDU $=$ Government Expenditure on education

$\mathrm{XHLT}=$ Government Expenditure on health

Where; $\beta_{0}=$ the Intercept

$B_{1}-\beta_{5}$ are the Coefficients of Independent variables and $U_{t}=$ Error term.

The unit root and the Error Correction Model (ECM) are generally presented as follows.

\subsection{Unit Root Model}

$$
\begin{gathered}
\Delta Y_{t}=\alpha Y_{t-1}+\sum_{i=1}^{m} B \Delta Y_{t-1}+\delta+Y_{t}+\varepsilon_{t} \text { (For levels) } \\
\Delta \Delta Y_{t}=\alpha \Delta Y_{t-1}+\sum_{i=1}^{m} B \Delta \Delta Y_{t-1}+\delta+Y_{t}+\varepsilon_{t} \text { (For first difference) }
\end{gathered}
$$

Where;

$\Delta \mathrm{Y}$ is the first difference of the series; $\mathrm{m}$ is the number of lags and $\mathrm{t}$ is the time.

\subsection{Error Correction Model}

The error correction model for two variables $\mathrm{X}$ and $\mathrm{Y}$ is stated generally as:

$$
\Delta Y_{t}=\alpha_{0}+\alpha_{1} \Delta X_{t}+\alpha_{2} U_{t-1}+\varepsilon_{t}
$$

Where; $\alpha_{2}$ is the degree of adjustment.

\section{0 RESULTS AND DISCUSSIONS}

The empirical analysis of data in this paper was conducted in four phases. It begins with the descriptive statistics analysis of the data and thereafter conducted the unit test. Furthermore, co-integration and the error correction mechanism were conducted.

\subsection{Descriptive Statistics}

The result of the descriptive statistics is presented in Table 4.1 below.

Table 4.1 Descriptive Statistics

\begin{tabular}{l||llllll}
\hline \hline & CPI & XTCM & XDFS & XAGR & XEDU & XHLT \\
\hline \hline Mean & 19.35040 & 14.41289 & 95.38184 & 16.55474 & 110.9403 & 65.30237 \\
Median & 12.71577 & 5.535000 & 45.23500 & 6.700000 & 41.74500 & 15.93000 \\
Maximum & 72.83550 & 90.03000 & 442.1500 & 65.40000 & 465.3000 & 296.4400 \\
Minimum & 5.388008 & 0.030000 & 0.540000 & 0.010000 & 0.160000 & 0.040000 \\
Std. Dev. & 17.24364 & 19.94717 & 131.7519 & 20.06081 & 145.2290 & 90.46229 \\
Skewness & 1.741920 & 2.002061 & 1.310115 & 0.944058 & 1.144717 & 1.237664 \\
Kurtosis & 4.838732 & 7.418385 & 3.268189 & 2.566919 & 2.819851 & 3.097758 \\
Jarque-Bera & 24.57028 & 56.29561 & 10.98443 & 5.941521 & 8.350441 & 9.716605 \\
Probability & 0.000005 & 0.000000 & 0.004119 & 0.051264 & 0.015372 & 0.007764 \\
\hline \hline Observations & 38 & 38 & 38 & 38 & 38 & 38 \\
\hline \hline
\end{tabular}

Source: Authors own computation using E view 10

From Table 4.1, the result shows that the standard deviation calculated for government expenditure on education (XEDU) was the most volatile in the series with a value of 145.2290 while consumer price index (CPI) was the least volatile variable with a value of 17.25511. The calculated values for the skewness statistic for all the variables - CPI, XTCM, XDFS, XAGR, XEDU, and XHLT were 


\section{Public Expenditure and Inflation in Nigeria}

positively skewed, suggesting that their distributions have a long right tail. The kurtosis statistics for XAGR and XEDU were platykurtic, meaning that their distributions were flat relative to normal distribution while CPI and XTCM were leptykurtic, meaning that their distributions were peaked relative to normal distribution whereas XDFS and XHLT were normally distributed. Based on these observations, it therefore means that there is unit root (non-stationarity) in the series. Thus, estimating these variables at level might not give good results, hence, the need to conduct the unit root test. The unit root test is conducted to test whether or not the variables were stationary. The study adopts the Augmented Dickey Fuller (ADF) unit root tests procedures.

\subsection{Unit Root Test}

The results of the unit root test using the ADF are reported in Table 4.2. The result shows that all the variables CPI, XTCM, XDFS, XAGR, XEDU, and XHLT were stationary in their $1^{\text {st }}$ difference as shown in the table below.

Table 4.2 Unit Root Test using Augmented Dickey-Fuller (ADF) Test

\begin{tabular}{|c|c|c|c|c|c|c|}
\hline \multirow[t]{2}{*}{ Variables } & \multicolumn{4}{|c|}{ Augmented Dickey-Fuller Test } & \multirow{2}{*}{$\begin{array}{l}\text { Order of } \\
\text { int. }\end{array}$} & \multirow[t]{2}{*}{ Remark } \\
\hline & @ level & @ $1^{\text {st }}$ Diff & $5 \%$ C. V & Lag & & \\
\hline $\log (\mathrm{CPI})$ & -4.392622 & -6.673382 & -3.540328 & Maxlag $=9$ & $I(1)$ & Stationary \\
\hline $\log (\mathrm{XTCM})$ & -2.417373 & -8.017637 & -3.540328 & Maxlag=9 & I (1) & Stationary \\
\hline Log(XDFS) & -2.304855 & -7.543729 & -3.540328 & Maxlag=9 & I (1) & Stationary \\
\hline $\log (X A G R)$ & -2.156112 & -6.832882 & -3.540328 & Maxlag=9 & I (1) & Stationary \\
\hline $\log (X E D U)$ & -3.120673 & -5.732531 & -3.540328 & Maxlag=9 & I (1) & Stationary \\
\hline $\log (\mathrm{XHLT})$ & 0.017880 & -5.264052 & -3.540328 & Maxlag $=9$ & I (1) & Stationary \\
\hline
\end{tabular}

Source: Author's own computation using E view 10

\subsection{Co-integration test result and Analysis}

Having ascertained the stationarity status of the variables we proceed next to consider if there exists at list a linear combination of the variables with unit roots that is stationary using the Johansen full information maximum likelihood method.

Table 4.3a: Unrestricted Cointegration Rank Test (Trace)

\begin{tabular}{lllll}
\hline $\begin{array}{l}\text { Hypothesized } \\
\text { No. of CE(s) }\end{array}$ & Eigenvalue & $\begin{array}{l}\text { Trace } \\
\text { Statistic }\end{array}$ & $\begin{array}{l}\mathbf{0 . 0 5} \\
\text { Critical Value }\end{array}$ & Prob.** \\
\hline \hline None ${ }^{*}$ & 0.861021 & 181.4224 & 95.75366 & 0.0000 \\
At most 1 & 0.756382 & 110.3789 & 69.81889 & 0.0000 \\
At most 2 & 0.572649 & 59.54127 & 47.85613 & 0.0028 \\
At most 3 & 0.365576 & 28.93589 & 29.79707 & 0.0626 \\
At most 4 & 0.242508 & 12.55452 & 15.49471 & 0.1322 \\
At most 5 & 0.068533 & 2.555793 & 3.841466 & 0.1099 \\
\hline \hline
\end{tabular}

Source: Author's own computation using E view 10

From Table 4.3, the Johansen co-integration procedure of the model depicts that trace statistics shows that there 3 cointegrating equations. This means that all the explanatory variables (XTCM, XDFS, XASR, XASR, XEDU and XHLT) are co-integrated with inflation (CPI) in Nigeria within the period under consideration (1981-2018). In order words, there is a long run relationship between the dependent and independent variables.

\subsection{Parsimonious ECM test result and Analysis}

In order to confirm the existence of a co-integrating vector among the variables, the ECM was employed. This is based on the general-to-specific rule and the results are presented on table 4.4 below.

Table 4.4: Parsimonious ECM Result

Dependent Variable: DLOG(CPI)

\begin{tabular}{|c|c|c|c|c|}
\hline Variable & Coefficient & Std. Error & t-Statistic & Prob. \\
\hline$C$ & -0.072095 & 0.147251 & -0.489606 & 0.6315 \\
\hline
\end{tabular}


Public Expenditure and Inflation in Nigeria

\begin{tabular}{|c|c|c|c|c|}
\hline DLOG(CPI(-1)) & 0.824955 & 0.257456 & 3.204258 & 0.0059 \\
\hline DLOG(CPI(-2)) & -0.282851 & 0.202196 & -1.398891 & 0.1822 \\
\hline DLOG(XTCM) & 0.233205 & 0.161635 & 1.442792 & 0.1696 \\
\hline DLOG(XTCM(-2)) & 0.288171 & 0.144914 & 1.988565 & 0.0653 \\
\hline DLOG(XTCM(-3)) & -0.191648 & 0.164260 & -1.166736 & 0.2615 \\
\hline DLOG(XDFS) & 0.238282 & 0.384387 & 0.619900 & 0.5446 \\
\hline DLOG(XDFS(-2)) & 0.537741 & 0.382912 & 1.404346 & 0.1806 \\
\hline DLOG(XAGR) & -0.143062 & 0.174728 & -0.818770 & 0.4257 \\
\hline DLOG(XAGR(-1)) & 0.271781 & 0.195877 & 1.387508 & 0.1856 \\
\hline DLOG(XAGR(-3)) & 0.133240 & 0.195980 & 0.679866 & 0.5069 \\
\hline DLOG(XEDU) & 0.233526 & 0.343257 & 0.680323 & 0.5067 \\
\hline DLOG(XEDU(-2)) & -0.195616 & 0.225910 & -0.865900 & 0.4002 \\
\hline DLOG(XEDU(-3)) & -0.488590 & 0.287122 & -1.701677 & 0.1094 \\
\hline DLOG(XHLT) & -0.547090 & 0.290849 & -1.881009 & 0.0795 \\
\hline DLOG(XHLT(-3)) & 0.599973 & 0.306596 & 1.956882 & 0.0692 \\
\hline $\operatorname{ECM}(-1)$ & -0.661150 & 0.243959 & -2.710086 & 0.0161 \\
\hline
\end{tabular}

$\mathrm{R}^{2}=0.785706 ;$ F-statistic $=13.05403, \operatorname{Prob}($ F-statistic) $=0.016858$, D.W. $=2.036016$

Source: Author's own computation using E view 10

Table 4.4 shows that the value of government expenditure on transport and communication (XTCM) has a positive impact on inflation (CPI) but not significant at 5\% level. This implies that an increase in government expenditure on transport and communication (XTCM) increases inflation (CPI) in Nigeria within the period of study. The coefficients of government expenditure on transport and communication (XTCM) do not conform to a priori in line with economic theory.

Furthermore, the results indicate that the coefficient of the value of government expenditure on defense (XDFS) has a positive effect on inflation rate, suggesting that an increase in government expenditure on defense (XDFS) increases inflation (CPI) in Nigeria within the period under review. The coefficient of government expenditure on defense (XDFS) does not conform to our a priori in line with economic theory and do not impact significantly on inflation (CPI) in Nigeria.

Also, the coefficient of current value of government expenditure on agriculture (XAGR) is negative suggesting that an increase in government expenditure on agriculture (XAGR) decreases inflation (CPI) in Nigeria within the period under review. The coefficient of government expenditure on agriculture (XAGR) conforms to our a priori expectation which is in line with economic theory and does not impact significantly on inflation (CPI) in Nigeria.

The coefficient of current value of government expenditure on education (XEDU) is positively related to inflation rate suggesting that an increase in government expenditure on education (XEDU) increases inflation (CPI) in Nigeria within the period under review. The coefficient of government expenditure on education (XEDU) conforms to our a priori in line with economic theory and does not impact significantly on inflation (CPI) in Nigeria. While the coefficient of the current value of government expenditure on health (XHLT) is negatively related to inflation rate suggesting that an increase in government expenditure on health (XHLT) decreases inflation (CPI) in Nigeria within the period under review. The coefficient of government expenditure on health (XHLT) conforms to our a priori in line with economic theory and does not impact significantly on inflation (CPI) in Nigeria.

Again, the result shows that the calculated coefficient of determination ( $R$ square) is 0.7857 , indicating that the regressors in the model account for about 79 percent of the total variation in CPI. The remaining 21 percent are due to factors exogenous to the model but covered by the error term. That means the regression line has a good fit. Also, the overall regression result of the dynamic model is significant at 5 percent level as shown by the F-calculated of 13.054 . The ECM is rightly signed and is also significant. It shows about 66 percent disequilibrium in CPI in the previous year is corrected in the current year since the data used are annual. Also, the Durbin-Watson (D-W) statistics value is 2.03, meaning that there is no serial autocorrelation in the model. Conclusively, the empirical result in this paper is agreement with the works of Egbulonu and Wobilor (2016), Ojarikre, Ezie and Torka (2015) and Ogbonna (2014) but in disagreement with the work of Cynthia (2018). 


\section{Public Expenditure and Inflation in Nigeria}

\subsection{CONCLUSION AND RECOMMENDATIONS}

This paper empirically examined the effect of public expenditure on inflation in Nigeria from 1981 to 2018. The study adopts descriptive statistics, Co-integration and Error Correction Mechanism techniques for the analysis. The data for the empirical analysis were sourced from secondary sources like CBN Statistical Bulletin. The results of analysis indicated that a long run relationship exists among the variables. Furthermore, the paper revealed that government expenditure on transport and communication (XTCM) has a positive but not significant relationship with inflation (CPI); government expenditure on defense (XDFS) is positive and an insignificant effect on inflation (CPI) in Nigeria; government expenditure on agriculture (XAGR) is negative and an insignificant effect on inflation (CPI) in Nigeria; government expenditure on education (XEDU) is positive and an insignificant effect on inflation (CPI) in Nigeria and government expenditure on health (XHLT) is negative and an insignificant effect on inflation (CPI) in Nigeria.

Based on the above findings, the paper recommends as follows:

(1) Government should not play politics with expenditure on public goods just to win cheap popularity.

(2) Government should monitor the contract awarding process of capital projects closely, to prevent against over estimation of execution cost. This will bring about significant impact of public investment spending on the general price of goods and services.

(3) There should be effective channeling of public fund to productive activities, which will help in stabilizing the general prices of goods and services.

(4) The government consumption spending should be well coordinated by all arms of government to prevent "Crowd out" effect on government investment.

\section{REFERENCES}

1) Adeyeye, E. A \& Fakiyisi, T.O (1980). Productivity Prices and Income board and anti-inflationary policy in Nigeria. The Nigeria economy under the military, Nigerian Economic Society. Ibadan: Processing of the 1980 annual Conference.

2) Aizenman, J. and Hausman R. (2000). "The impact of inflation on budgetary discipline" Journal of Development Economics $63,425-449$.

3) Akinnifesi, E.O (1977, 184). In Cynthia, C.D (2018). Public spending and inflation in Nigeria. International Journal of Advance Academic Research Social and Management Science Vol. 4.

4) Anyanwu, JC (1997). Nigeria Public Finance: Onitsha: Joanee. Educational Publishers Ltd.

5) Asogu, J.O. (1991). An Econometric Analysis of the Nature and causes of inflation in Nigeria. Central Bank of Nigeria Economic and Financial Review, Lagos.

6) Bhartia, H.L. (2006). Public Finance, New Delhi: Vikas publishing House PVT Ltd.

7) Central Bank of Nigeria (2011). Statistical Bulletin, Abuja.

8) Central Bank of Nigeria (2017). Statistical Bulletin. Lagos: Central Bank of Nigeria.

9) Cynthia, C.D (2018). Public spending and inflation in Nigeria. International Journal of Advance Academic Research Social and Management Science Vol. 4.

10) Egbulonu, K.G., and Wubilor, A.K. (2016), Impact of fiscal policy on inflation in Nigeria, Economy. International Journal of Innovative Development and Policy Studies 4(3), $53-60$.

11) kEverton, Vincent and Wilvon (2012). Public Spending and Inflation in Nigeria. International Journal of Advance Academic Research Social and Management Science Vol. 4.

12) Ezirim, C.B. Moughalu, M.I and Elike, U (2008). "Inflation versus public Expenditure Growth in the US: and Empirical Investigation," North American Journal of finance and Banking Research, 22.

13) Ezirim, C.B. Moughalu, M.I and Elike, U (2010). "Public Expenditure Growth, Inflation and Co-integration: Evidence from Nigeria," International Journal of Business and Behavioral Sciences Research, (1): 1-16.

14) Jhingan. M.I (2004b). Money, Banking, International Trade and Public Finance ( $7^{\text {th }}$ ed New Delhi: Vrinda Publication (p) Ltd.

15) Kia, A., (2006). Deficits debt financing, monetary policy and inflation in developing countries: Internal and external factors? Evidence from Iran". A journal of Asian Economics 17,879-903.

16) Maku, O.E. (2009). Does government spending spur Economic growth in Nigeria? Munich Personal Rc PEc Archive.

17) Medee, P.N. and Nenbee, 5.G (2012). The impact of fiscal deficits on inflation in Nigeria. International journal economic development Research and investment, 3(1), $12-21$.

18) Mehraraa, M., Soufianib, M. B and Rezaei, S (2016). The impact of Government spending on inflation through the inflationary environment, STR approach. World Scientific News (WSN), 37, 153-167.

19) Musgrove, R.A. and Musgrove, P.B (2004). Public Finance in Theory and Practice. New Delhi: Tata McGraw Hill. 


\section{Public Expenditure and Inflation in Nigeria}

20) Nyambe, J.M and Kanyeumbo, J.N. (2015). Government and household expenditure components, inflation and their impact on economic growth in Namibia. Journal of Business, Economics and Accountancy, 6(15), 36-41.

21) Ogbole, O.F., and Nenbee, S.G (2012). The impact of fiscal deficits on inflation in Nigeria International journal of economic development Research and investment, 3(1), 12 - 21.

22) Ogbonna, B.C. (2014). Inflation dynamics and government size in Nigeria. International journal of Economics, commerce and management United Kingdom, 11(12), 1 - 22.

23) Ojarike, O.J, Ezie, O and Torka, T.M (2015), Public expenditure growth and inflation in Nigeria: The causality approach. International journal of Economics and management studies, 2(1), $26-35$.

24) Olaiya, S.A, Nwosa, P.I and Amassoma D. (2012); a Trivariate causality Test among Economic Growth, Government Expenditure and Inflation Rate: Evidence from Nigeria, Research Journal of Finance and Accounting, 3, (1).

25) Olayunbo, D.O. (2013). Government spending and inflation in Nigeria: An Asymmetry causality Test. International journal of Humanities and management Sciences (IJHMS), 1(4), 238- 242.

26) Osakwe, J.O. (1983). Government Expenditure, Money supply and Prices, 1970 - 1980" CBN Economic and Financial Review, 21(2).

27) Ozurumba, B.A. (2012). Fiscal Deficit and Inflation in Nigeria: causality Approach, International journal of Scientific and Technology Research, 1(8): 1-12.

28) Peter, G.A. (2015). Effects of public expenditure on selected macroeconomic variables in Nigeria: 1986 - 2012 . An unpublished thesis submitted to Department of Economic, faculty of social sciences Ahamadu Bello University Zaria.

29) Udu, E (1989), “New system Economics” African Publishers Ltd, Onitsha. 